Светлана М. Стругаревић*

УДК 524.8

Докторанд

ДОИ https://doi.org/10.18485/analiff.2017.29.2.11

Универзитет у Београду

Филолошки факултет

\title{
НОМЕНКАЛТУРА И ИКОНОГРАФИЈА ЗВЕЗДА И САЗВЕЖЂА У АРАБЉАНСКОЈ ТРАДИЦИЈИ И ОРИЈЕНТАЛИЗАЦИЈА КЛАСИЧНЕ ХЕЛЕНИСТИЧКЕ АСТРОНОМИЈЕ ${ }^{1}$
}

Астрономија је била изузетно значајна у средњовековном исламском свету, а данас смо сведоци њених достигнућа у модерној науци. Копије и преписи ислустрованог, астрономског рукописа Kitāb șuwar al-kawākib al-tābita Абдулрахмана ел Суфија² су преживеле до данас и представљају основу овог рада. Суфи нам је оставио списак 48 сазвежђа из Птоломејевог Алмагеста, као и информације о традиционалним сазвежђима и именима звезда у преисламској Арабији. Пошто су сазвежђа замишњене слике на небеском своду, њихова имена и представа у облику различитих фигура нам говоре занимљиве приче о култури и интересовањима народа који су их створили. Проучавањем културне транслације и транслитерације кроз номенклатуру и иконографију сазвежђа, лако можемо да разумемо о чему су бринули и чему су се надали Бедуини, да приметимо културолошке разлике између древних Грка и растуће исламске цивилизације у златном периоду њеног развитка. Посматрањем трансформација илустрација, посебно када je у питању приказивање људске фигуре, лако можемо да пратимо историју исламске цивилизације и мешавину културних утицаја који су пратили територијалну експанзију и освајања.

Кључне речи: Исламска цивилизација, арапска астрономија, сазвежђа, арапски рукописи, 'Abd al-Raḥman al-Șūfi, Абдулрахман ел Суфи, Kitāb Șuwar al-kawākib al-țābita

*_ svetlanastrugarevic90@gmail.com

1 Рад је усмено изглаган на конференцији Interdisciplinary research in civilization studies, одржаној у Истанбулу 5-6. новембра 2016. године под насловом: Studying the Medieval Islamic Civilization Through the Nomenclature and the Iconography of the Stars and the Constellations in The Book of the Fixed Stars: Arabian Tradition and Orientalization of Hellenistic Astronomy

2 'Abd al-Raḥman al-Șūfi; у тексту се користи ЗДМГ транксрипција 
Неоспориво је да је астрономија била једна од најзанчајнијих наука у средњовековном арапском свету. Међутим, због оскудних извора и литературе, не зна се пуно о астрономији пустињског народа у преисламског Арабији. Један од главних извора за ова знања је дело научника Абдулрахмана ел Суфија из 10. века, које је обухватило дотадашња знања у астрономији која се тичу кретања, положаја, номенклатуре и илустрације звезда и сазвежђа. Неки Суфију замерају што је као извор за арабљанску традиционалну астрономију узео народне пословице, песме, легенде и приче, али других извора о овом периоду и нема. Уз то, народ је и у Суфијево време, па и данас, одлично познавао звезде и сазвежђа која су им помагала у оријентацији, те се њихова знања не могу занемарити.

У прво делу ово рада се, користећи пре свега Суфијеву књигу о сазвежђима șuwar al-kawākib al-tāaita, наводе арабљанска имена звезда, онако како их је народ лакше налазио на небу и под којим именом их и данас многи знају. У истом делу ће бити наведена сазвежђа из арабљанске традиције, њихове одлике и разлике у схватањима у односу на Вавилон, Сумер и античку Грчку.

У другом делу рада ће се говорити о транслацији и транслитерацији назива звезда и сазвежђа који су преузети из Птоломејевог Алмагеста³ До каквих је промена долазило, шта се разликовало у ове две културе, а шта је било исто, најбоље ће нам показати иконографија и номенклатура сазвежђа. Суфијево дело и ту има предност јер најстарији сачувани рукопис потиче из 1009/10. године. Илустрације сазвежђа у њему су од изузетног значаја како научно, тако и уметнички и културолошки.

\section{Сазвежђа као Роршахове мрље цивилизација}

Човек је одувек гледао у небо, посебно ноћу, када су звезде биле једини начин за оријентацију и навигацију. Посматрајући кретања на ноћном небу, за примитивног човека је постало нормално да именује групе звезда по неким облицима из свакодневног живота како би

3 Алмагест је математички и астрономски трактат из 150. године који је саставио Птоломеј. У оригиналу се звала Mathēmatikē Syntaxis или Magna Syntaxis, а на арапски је назив преведен као al-Magistī . Када је трактат са арапског превођен на европске језике, латинизовано је његово арапско име, а код нас је дело познато као Алмаїесй. 
НОМЕНКАЛТУРА И ИКОНОГРАФИЈА ЗВЕЗДА И САЗВЕЖЪА У АРАБЉАНСКОЈ...

их лакше упамтио: људским бићима, животињама или предметима. Други корак је идентификовање ових небеских облика са митолошким представама, повезујући их у једну велику небеску слику. Птоломеј каже да приликом сликања ових фигура не би требало истицати бојом њих, већ звезде како би посматрачу било јасно да ови замишљени облици служе само како би се лакше запамтило оно што постоји на небу (Wellesz, 1959: 2-3).

Као што на основу архитектуре, сликарства, књижевности, музике и одеће можемо створити слику о једној цивилизацији, тако је лако можемо створити и на основу њихове идеје о фигурама сазвежђа. Фигуре и облици које су људи у машти видели на небеском своду, говоре доста о култури и преференцијама тог одређеног народа. Тако се ствара дубља слика о њиховим бригама и размишљањима, те, како Моја Кери каже: „Сазвежђа представљају својеврсне Роршахове мрље на небу за народе и културе“" (Carey, 2008).

И Грци и Арабљани у преисламском периоду су идеје о сазвежђима преузели из вавилонске традиције, али су их прилагодили својим спознајним оквирима, помешали са претходним знањима и временом изменили у свом духу. Ако узмемо древну Грчку као пример, на небеској сфери су се одигравале митолошке сцене и антопоморфне фигуре су биле у центру пажње. На небо су уздигнути богови, хероји и разна чудовишта.

Бедуини су за разлику од старих Грка били дефинисани пустињским начином живота. Живот сточара и пастира, путника који користе ноћ како би избегли високе дневне температуре и траже оријентир у природи, као и племенски живот, шатори, изначај индивидуе само уколико може допринети заједници, се огледају у сазвежђима. На арабљанском небу су камиле, шакали, хијене, лавови, газеле, ловци, ратници, пастири и њихови пси, стадо, шатори, нојеви и њихова гнезда, рибе. Људске фигуре су приметно ређе (Upton, 1933: 179).

\section{Арабљанска астрономска традиција}

Арабљани су много пре ислама, као номади, имали своје идеје о сазвежђима и звездама. Посматрали су њихова кретања и памтили положаје најкориснијих. Поред одређивања времена током 
дана и времена за жетву и сетву (Upton, 1933: 179), бедуинима је астрономија, посебно познавање положаја звезда на небеској сфери, била од животне важности. Избегавање дневних врућина је терало Арабљане да путују ноћу. Као оријентир су им служиле звезде.

И данас су у пустињи звезде најсигурнији начин сналажења и оријентације јер у пустињи не постоји лево или десно у осносу на нешто. И данас бедуини и путници по пустињи знају: сазвежђе Велики медвед се користи како би се одредила Северњача, а ако Велики медвед зађе за хоризонт, Северњачу ће показати Касиопеја (Malek, 2011).

Није ни чудо што је и најпростији народ знао да именује звезде и да их пронађе на небу, како сам Суфи каже. Астрономија је била потребна за преживљавање.

Сигурно је да су као и стари Грци, Арабљани преузели зодијак и нека сазвежђа од Вавилонаца. Међутим, може се, донекле, утврдити тај утицај. У списима који су до данас сачувани, најдетаљнији и најстарији опис арабљанске астрономске традиције даје Суфи, обрађујући је упоредо са хеленистичком традицијом преузетом из Птоломејевог Алмагеста. Ту се може наслутити шта је преузето потпуно од Грка, која су сазвежђа постојала у истом или сличном облику и код Бедуина, а која су чисто арабљанског порекла. Чини се да је у арабљанској традицији сачувано много више вавилонског утицаја, али немогуће је одредити јасну границу са ове временске удаљености и без икаквих писаних докумената из преисламског периода о сазвежђима (Rogers, 1998: 23).

Поред сазвежђа која су преузета из Алмагеста, имамо и она која су постојала на обе стране уз мале разлике и често је превагнуо хеленистички елемент, то јест Птоломејев приказ. Орао (Aquila) je, на пример, сазвежђе које је преузето из хеленистичке традиције али је већ постојало као такво у бедуинској, тако да се може закључити да је извор учења био заједнички, вероватно Вавилон. Ту имамо као пример и сазвежђа зодијака, сазвежђе Кочијаш (Auriga), Брод (Argo Navis) и тако даље. Код Јарца (Capricornus) ce, рецимо, јасно види вавилонски утицај када се приказује са рибљим репом, као морска коза (Savage-Smith \& Belloli, 1985).

Ако су постојали оригинални прикази који су надјачали грчки утицај, често су то биле вавилонске идеје (Carey, 2001: 124). Сазвежђе

4 Није сигурно да ли су Арабљани називали бродом неко друго сазвежђе. 
Кит (Cetus) се никада не приказује као код Птоломеја, већ као источњачки змај са оковратником (Savage-Smith \& Belloli, 1985). Исто је са Девицом која се приказује као клас пшенице, а тако се и назива ${ }^{5}$, или Стрелцем ${ }^{6}$ који је често само лук без кентаура из класичног приказа. Ова идеја вероватно потиче из периода пре Алмагеста и толико је била снажна да је одолела грчком утицају, али њено порекло, још једном, није сигурно.

\section{Сазвежђа из арабљанске традиције}

Што се чисто арабљанских представа и идеја о сазвежђима тиче, јако је важно рећи да они нису добијали фигуре сазвежђа повезујући имагинарним линијама сјајне тачкице на небу. Фигуре на арабљанској небеској сфери нису биле мапе, већ више слободне слике које су заузимале одређену територију и укључивале одређене звезде. То су биле или огромне фигуре које су заузимале по неколико данашњих сазвежђа, или појединачно посматране звезде или групице звезда (Rogers, 1998 и Carey, 2001).

Сазвежђе Вук или Дивља звер и Кентаур су Арабљани посматрали као једно и називали гроздом или граном пуном датула или грожђа (al-šamārih ) јер их је густина звезда подсећала на то (Savage-Smith \& Belloli, 1985).

Бедуинска традиција у сазвежђу Пегаза познаје квадрат који формирају четири звезде и назива се Кофа ( $a l$-dalw), а данас је познато као Пегазов квадрат. Идеја о кофи која је везана канапом је потврђена и у називу звезде које Суфи наводи, al-karab или „место где је канап привезан за кофу“. Да је сазвежђе Кофа или неко сазвежђе са кофом постојало, сведочи и име звезде на Андромедном струку која се зове и al-riš $\bar{a}$ или канап који је везан за кофу у Пегазовом квадрату. За Водолију Суфи каже да је Кофа (Savage-Smith \& Belloli, 1985).

5 Al-sunbula је клас пшенице и тако се сазвежђе популарно називало. Данас је у хороскопима преовладао термин al-'ad̦ā' што значи девица.

6 Арабљани су вероватно од Сумера преузели представу о закривљеном луку, без људске фигуре или al-qaws. Људска фигура која одапиње стрелу је al$r \bar{a} m \bar{\imath}$ и преузета је из грчке традиције као кентаур. Ипак је данас прво име доминантно кад је у питању ово сазвежђе зодијака. 
Данашње сазвежђе Рибе се на арапском назива Кит (al-ḥut). Ово говори да је уместо две рибе, у арабљанској представи на овом месту била једна велика риба, која се вероватно протезала на много већој површини. Суфи у свом делу приказује сазвежђе Андромеде које се преклапа са сазвежђем из бедуинске традиције, Великом рибом. На струку Андромеде се налази звезда која се назива и batn al-ḥut или „рибљи трбух“, а по неким мишљењима, постојале су две различите рибе које су се преклапале с Андромедом (Savage-Smith \& Belloli, 1985).

Суфи за ову једну звезду у Касиопеји каже да се налази на грби женке камиле ( $n \bar{a} q a)$ штоје још једно сазвежђе из арабљанске традиције које је, наводно, обухватало звезде из Касиопеје и Андромеде. Са Андромедом се преклапало и сазвежђем коња (al-faras al-kāmil, „цео коњ“) које је Суфи илустровао (Savage-Smith \& Belloli, 1985).

За разлику од осталих арабљанских сазвежђа која не прате строго распоред звезда, поменута Камила, Коњ и Риба то раде, па се претпоставља да су ова сазвежђа до Арабљана стигла из вавилонске астрономије.

\section{Лав}

Од Суфија и других аутора сазнајемо за огромно сазвежђе које се зове Лав, али је много веће од истоименог сазвежђа зодијака и припада идеји о сазвежђима пре Алмагеста. Оно се протезало преко данашњих сазвежђа Рак, Лав, Близанци и Велики медвед. О томе сведоче имена звезда из арабљанске традиције:

- у сазвежђу Рак се налазе звезде al-natra (ноздрва или њушка), al-lahā (ресица у грлу), al-țarf (поглед) и al-ašfār (место где на капцима где почињу трепавице) и све се односе на тог Лава;

- сазвежђе зодијака Лав има на рамену звезду al-ğabha или чело „већег лава“, а осам звезда ван сазвежђа формирају завршетак репа тог огромног Лава;

- главе Близанаца се у бедуинској традицији називају al-dirā' или „предња нога“, што се још једном односи на овог Лава из арабљанске традиције.

Још једна идеја о овом Лаву се огледа у паровима звезда на стопалима Великог медведа које се називају газелиним или јелењим скоковима: al-qafzah al-'ūlā (први скок), al-qafzah al-tāniya (други скок) и al-qafzah al-tālita (трећи скок). Ови парови звезда су посматраче 
подсећала на газелу или јелена који у скоковима беже од лава. Доказ о идеји лавље фигуре на овом делу небеске сфере је и име једне од спољашњих звезда испод репа, kabid al- ’asad, што значи ,лавља јетра“.

\section{Ел Тураја}

Арабљани су на простору данашњих сазвежђа Андромеда, Бик и Персеј видели огромну женску фигуру која се називала ел Тураја (al-turayyā). Значење овог имена је нејасно али Суфи каже да су Арабљани били благословени његовим звездама, па се може превести као ,драгуљ“ или ,драгоценост“.

Сјајна звезда на подигнутом лакту Андромеде се назива al-kaff $a l-\underline{h} a d \bar{\imath} b$ или „обојена рука“. Мисли се на руку обојену каном. Суфи каже да су некад астрономи давали име једној звезди по целој групи звезда, што је случај и са овом. Наиме, у бедуинској традицији, ел Каф ел хадиб је назив за пет звезда у Млечном путу. Те звезде се налазе на Андромедином лакту, образу, појасу, крилу и на северној нози (она која је горња од две на нози). Те звезде су део сазвежђа џиновске жене, ел Тураје, из арабљанске традиције и чине њену руку, док јој главу чине Плејаде.

На оштрици Персејевог мача се налази звезда која се на неким глобусима назива mi șam al-turayy $\bar{a}^{7}$ (Турајин зглоб), а у сазвежђу су још и mankib al-turayyā (Турајино раме) и 'atiq al-țrayyā (Турајина лопатица) који још једном подсећају на ово старо арабљанско сазвежђе.

\section{Ел Џавза}

Још једно огромно сазвежђе из арабљанске традиције носи нејасно име ел Џаузаа ( $a l$-ğawzăa'), од корена који значи „венчати се“. Верује се да је у питању било сазвежђе у форми људске фигуре које је заузимало неколико данашњих сазвежђа. Ова људска фигура је највероватније била женско.

Данас се сазвежђе Близанци на арпаском зове ел Џавза. Суфи користи и име ел Таваман (al-taw'amān) што значи близанци али је прво остало прихваћеније. Имена звезда и у сазвежђу Орион

7 Суфи ову звезду обележава као saḥābi (облачаста, маглина). 
подсећају на постојање ове фигуре. У сазвежђу Зец и у сазвежђу Река или Еридан се налазе „столице“ за ел Џавза.

Велики пас на Јужној небеској хемисфери се назива пратиоцем ове огромне фигуре, а Зец се понекад приказује као пас и назива се пратиоцем Ориона.

\section{Звезде и астеризми}

Арабљани су познавали имена најсјајнијих звезда и оних које су им биле занимљиве на небеским сликама, обраћајући пажњу, чини се, више на појединачне звезде и астеризме него на огромна сазвежђа у којима су се налазиле. Сазвежђа су вероватно само служила да би се лакше означила одређена област у којој су циљне звезде.

Како би се дух бедуинске традиције и мотиви који су их инспирисали најбоље приказали, навешћемо списак звезданих имена које даје Суфи у свом делу као део арабљанске традиције и онако како их народ познаје и лакше препознаје. Нека од тих имена, рецимо за три „скока“ у Великом медведу, се користе и у савременој астрономији, прилагођена изговору неарапског говорника, али очигледног порекла.

Сазвежђе Мали медвед, познато и као Мала кола или Мала кутлача, су Арабљани видели као посмртна носила и три девојке или ћерке које их прате оплакујући, о чему сведочи и banāt na ‘̌s al-ṣugrā (мале кћери носила). На предњој нози медведа и на рамену су сјајније звезде које су називане воловима, farqadān, који вуку носила. Притом је звезда на рамену 'ahfā al-farqadayn, „тамнији во од два вола“, а звезда на нози 'anwar al-farqadayn, „светлији во“.

Звезда на крају репа, Северњача, и најближа је северном небеском полу, називала се и $a l$-ğad̄̄ (коза). Звезда која се налази ван фигуре медведа, а припада сазвежђу, називана fa's al-rahā, што би значило да припада млинском камену на чијем се ободу налази док је центар млина тачка на Северном полу.

Група звезда на репу и пола трупа Великог медведа у арабљанској традицији се назива „Велике кћери носила“ у односу на претходно поменуте „мале“. Четири звезде формирају носила al-na $\breve{s}$, а три звезде у репу су al-banāt, девојке или ћерке. Имена звезда у репу, за разлику од осталих која су преузета из Алмагеста, потичу 
из арабљанске традиције. Прва звезда на репу медведа је al-ğawn (црни коњ), у средини је $a l-' a n \bar{q} q$ (коза), а последња је al-qā'id (вођа погребне поворке). Мала звезда поред средње у репу није наведена код Птоломеја, али Суфи каже да се зове $a l$-suhā (превиђена) и да се традиционално користи за тестирање вида.

Међу најчешћим мотивима у номенклатури звезда код Арабљана су ној, камила, пас и пастир. Близина Млечног пута Стрелцу је утицала на имена четири звезде које улазе у ,реку“ и четири које излазе. Оне се називају нојевима или na 'á ' im. Суфи наводи девет звезда које се називају al-qalà' is (млади нојеви) или al-qilāda (огрлица). На крају воденог млаза Водолије је звезда коју Суфи назива al-ẓalim или „мужјак ноја“, поред традиционаног назива „рибља уста“. Тридесет четврта звезда сазвежђа Еридан или Река се назива такође al-zalìm. Између ове две звезде је неколико fi' āh al-na 'äm или „малих нојева“. Пет звезда јужно од Кита и две које су заједничке Еридану и Киту су Арабљани називали 'udī al-na 'ām (гнездо нојева). И пет звезда у трупу кита се такође називају нојевима. Corona Australis је била позната као гнездилиште нојева из Стрелца.

Четири звезде на глави Змаја бедуини су звали 'awd' id (мајке камиле), звезда на језику Змаја је al-rāfid (лутајућа камила) или alrāqiș (камила у касу), како је наводи Суфи. Суфи наводи и једну звезду коју Птоломеј није видео у овом сазвежђу. Налази се између четири „мајке камиле“ и зове ce al-ruba ' (млада камила).

У његовом предњем делу Делфина се налазе четири сјајне звезде које се називају ел al-qa'ūd (млада камила) или al-'uqud (огрлица) у зависности од извора и преписивача. Неки ове звезде називају и крстом, al-salīb, док Суфи тај назив приписује звездама у репу Делфина. И на месту сазвежђа Гавран које је потпуно преоузето из Птоломејевог дела, Арабљани су виделі камиле, al-ă̆māl. У сазвежђу Бик се звезда Алдабаран (Lebling, 2010) некад називала и al-fanīq, „млади мужјак камиле“, јер је окружен младим женкама.

Имена звезда у Цефеју доказују старију арабљанску идеју о пастиру и псу на том делу неба, тако да имамо звезду $a l-r \bar{a} ' \bar{l}$ (пастир), „Две звезде стада“ које Суфи наводи или kawkabā al-firq, и звезду који Птоломеј није забележио kalb al-rā‘ Херкуловој глави је звезда која се такође зове $k a l b$ al-rā ‘ $\imath$, а у Шкоприји су два пса која завијају због надолазеће зиме. На глави Змијоноше се налази звезда која се традиционално назива „пастиром“, а Суфи каже 
да се око пастира налазе и два пса. Између четврте и седме звезде на змији се налази простор који се по Суфију назива ливадом al-rawda, и ту пастир чува стадо са псима.

У сазвежђу Троугао се налазе две звезде - al-anīsān, „два пријатеља“, а поред „огрлица““ у Стрелцу и Делфину, и Орионов појас ce назива al-nazm или al-nizām што значи „бисерна огрлица“. На репу Кита се налази звезда al-dafda' al-țā̄ (друга жаба), а Прва жаба је у Водолији. Риса или дивљу мачку, 'anāq al-’ard, налазимо у Андромеди; Гавран је замишљан као шатор, $a l-\underline{h} i b \bar{a}$, а на идеју о шатору наилазимо и у Јужној круни, al-qubba. Уз кичму Змаја, испод уста, налази се $a l$-dib или вук, а Суфи помиње још два вука. Друга звезда јужно од вука је aldih (хијена). Најзападније звезде сазвежђа Лира носе дух арабљанске традиције где се једна звезда назива nasr wāqi' (падајући орао), док се три звезде троугласто постављене називају „ногарима троношца“ или $a l$-atāfi. Троножац или сточић који помаже при кувању кафе налазимо и у Ориону. На репу Лава у овом сазвежђу је звезда șarfa (промена) и по веровању је повезана са променом времена.

У арабљанскојтрадицијипостојезвездекојесезову $\left.s a^{\prime} d\right)$. Слободан превод овог термина је „знак“, „знамен“ или „предсказање“(SavageSmith \& Belloli, 1985). На врату Пегаза су sa 'd al-humām (знамен града или сузнежице), на стомаку је $s a^{\prime} d$ bāri ' (добар знамен), а на нози sa'd matar (знамен кише). Суфи две на глави назива sa 'd al-bihām (знамен младих животиња или животињских принова). У сазвежђу Јарац, на глави фигуре налазе се две звезде које се називају sa 'd al-dabih отприлике, значи „знамен жртве“. Према Суфију, бедуини су једну звезду на рогу звали „жртвеним јагњетом“. Две најсјајније звезде у телу Јарца су sa'd nāšira или „знамен плодности“. У Водолији су и sa'd al-su'ud (знемен среће) и sa'd al-malik (краљевски знамен).

\section{Транслација и транслитерација хеленистичке астрономије}

Мада се астрономија изучавала много раније, код Арабљана се ова наука утемељила у 7. веку под утицајем индијских књига као што je Brahmasphutasiddhanta и Aryabhata. Ипак, највећи утицај је у 8. веку извршила грчка астрономија и превод Птоломејевог Алмагеста на арапаски језик (Upton, 1933: 179). 
Појава ислама никада није спречила развој наука, а посебан полет је дала астрономији чији су прорачуни били потребни како би се одредило време за пет дневних молитви и смер кибле (смер у ком се налази Мека). Такође је подстицано превођење, а посебан процвет науке су доживеле у 9. и 10. веку који се сматра златним периодом исламске цивилизације.

Значај и слобода коју је астрономија имала огледа се у њеном кршењу две забране у исламу: приказивања ликова и предвиђања будућности. Саставни део астрономије је била астрологија. Веровало се да звезде утичу и на људске жвоте, посебно сазвежђа зодијака, и пре појаве ислама. Упркос појави ислама, астрологија је наставила да се практикује, мада је према званичним учењима будућност и судбину само Бог зна. Сачуване су читаве књиге хороскопа за владаре.

Што се тиче приказивања ликова, посебно пре 12. века, нема пуно сачуваних дела која су илустрована на начин на који је илустрован Суфијев трактат о сазвежђима (Carey, 2008). У иконографији сазвежђа, била она научна или псеудонаучна (намењена астролошкој пракси), прихваћена је класична хеленистичка иконографија, уз неке изузетке. Свакако, долазило је до промена који осликавају културолошке разлике. Изменама су најподложнија била имена сазвежђа и фигуре које су уско повезане са старогрчком митологијом коју Арапи или нису познавали или их није занимала.

Кроз преписе Суфијеве поменуте књиге која је била изузетно популарна може се пратити даљи развој иконографије сазвежђа и промена у стилу. Са исламом се од 7. века ширила и наука, негде се намећући, негде примајући достигнућа других народа који су постајали Арапи. Пошто је арапски свет тада обухватао огроман простор и разне културне утицаје, јасно је зашто је долазило до варијација у костимима, украсима на глави, цртама лица и реквизитима који иду уз сазвежђа у зависности од простора и времена када настају рукописи и илустрације у њима. Но, то неће бити тема овог рада јер је наш циљ представљање првих измена и оријентализације хеленистичке астрономије.

Нека сазвежђа су просто преузета, као на пример Гавран, Троугао, Вук и друга која не осликавају културни диверзитет. До малих измена долази код сазвежђа Corona Borelais које није приказано као венац или круна већа као два концетрична круга дрхтавих ивица без задржавања 
на објашњењу њиховог значења. Лабуд је постао уопштено нека Птица или Кокошка код Арапа. Лира се назива корњачом, што опет има своје корене у хеленистичкој традицији и начину на који се прави овај инструмент. Назива се и месинганим кастањетама и гуском. Осим мањих измена, нежива бића и животиње су остајали исти. Слична ситуација је и са сазвежђима Зодијака. Изузетак су једино Стрелац и Девица што је претходно објашњено.

До најзначајнијих промена долази код оних фигура на којима је обележена културолошка, географска или религиозна припадност. Фигуре сазвежђа се могу мењати по слободној вољи док год се поштује звездани оквир који симболизују. Дакле, долази до промена у изразима лица, одећи, предметима које фигуре држе, фризури и тако даље. Укратко, људске фигуре се оријентализују.

Кочијаш (Auriga) је, рецимо, оријентализован турбаном на глави, као и све остале мушке фигуре осим Цефеја који носи фригијску капу. У каснијим рукописима фригијску капу замењује шарбуш (šarbūšs), дводелна крзнена турска капа са високим, троугластим фронталним делом (Carey, 2001: 127). Код Цефеја се једино задржала и брада. У најранијим рукописима Суфијевог дела, све остале мушке фигуре су голобради младићи (Wellesz, 1959: 13), али ће касније доћи до промена. Жене су окићене огрлицама и минђушама, панталоне им изгледају као димије и виде се испод неколико слојева сукања или горње тунике. Њихова фризура, као и стил приказивања турбана код мушкараца су један од поузданих начина одређивања старости рукописа без дубље анализе. Фигуре никада нису биле голе, што није страно класичној хеленистичкој представи. Ако фигура носи мач, он је најчешће бивао замењен закривљеном источњачком сабљом или оружјем које личи на срп (код Херкулеса).

Змијоноша са змијом је постао Кротитељ змија у складу са оријентализацијом; због непознавања митова, Касиопеја је постала „Жена са столицом“, а Андромеда „Жена у ланцима“ или „она која никад није имала мужа“, како Суфи покушава да изведе значење њеног имена са грчког језика (Savage-Smith \& Belloli, 1985).

Три најзанимљивија примера у преузимању иконографије сазвежђа и изменама услед неразумевања или оријентализације су Орион, Стрелац и Персеј. 
Орион (слика 1) у једној руци по класичној представи носи лављу кожу (по некима штит), али је из неког разлога ова идеја сметнута с ума. И код Суфија, а и касније, Орион се приказивао као фигура чији је један рукав несразмерно дугачак како би обухватио звезде где је лавља кожа била.

Други пример је Стрелац (слика 2). Представа о овом сазвежђу, вероватно, потиче из Вавилона где је приказиван са крилима која су код Грка постала плашт, а код Арапа одмотан турбан који вијори на ветру.

И трећи пример је Персеј (слика 3) који је по грчкој легенди отсекао главу горгони Медузи. Преношењем слике и непознавањем идеје о жени са змијском косом, у арапској иконографији младић држи демонску брадату главу. Понекад држи три главе или главу са три лица, али најчешће се на главама налази брада која је некада била крв из Медузиног врата (Carey, 2001: 102). Највећа звезда међу онима које чине одсечену главу се назива $\mathrm{ra}$ 's al-giv $l$ или гулова, демонска глава (Șūfî, 1981), а то име је прихваћено и у данашњој астрономији.

За крај ћемо дати један пример који нема везе са арбљанском традицијом или са арапском средњовековном астрономијом уопште, али показује како су легенде о сазвежђима променљиве у зависности од културе, чиме се потврђује да су она својеврсне Роршахове мрље народа и цивилизација. Легенда о спавачима постоји у хришћанској и исламској традици с малим разикама. У веровањима алавита из Киликије у Турској који нису исто што курдски алевити, за ово сазвежђе је везана легенда о седам спавача који су се након буђења уздигли на небо и постали седам звезда у делу овог сазвежђа. Пас који је пратио пастира је осма, слабија звезда ${ }^{8}$. То је по тумачењу неких шејиха 'Alī bin 'Abī Țālib9 ( који се указао спавачима као пас како би тестирао њихову веру (Crossen \& Procházka, 2007). У овој легенди се, рекло би се, огледа преплитање преисламских и исламских веровања. Могуће је да су се те звезде називале пастиром или његовим псом много раније, али су у алавитском шиизму ове области, та имена објашњена на нови начин.

8 То је Суфијева al-suhā или превиђена звезда која се користи за тестирање вида која се помиње раније у тексту.

9 У алавизму није страна персонификација небеских тела, а Алија често повезују са небом, Сунцем и Месецом. 


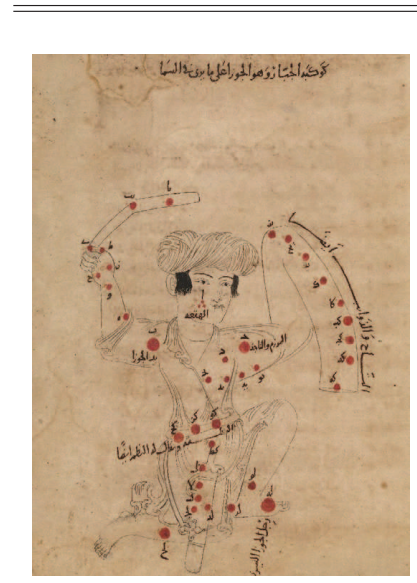

Слика 1.

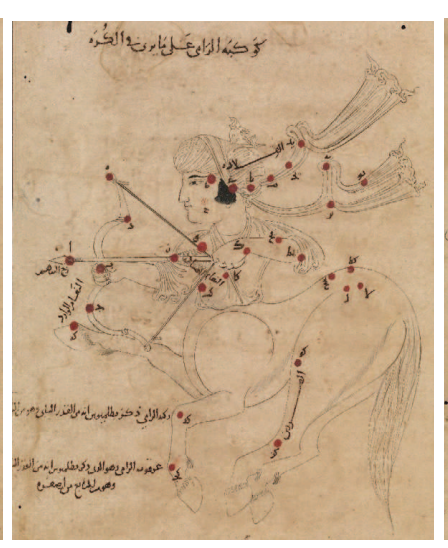

Слика 2.

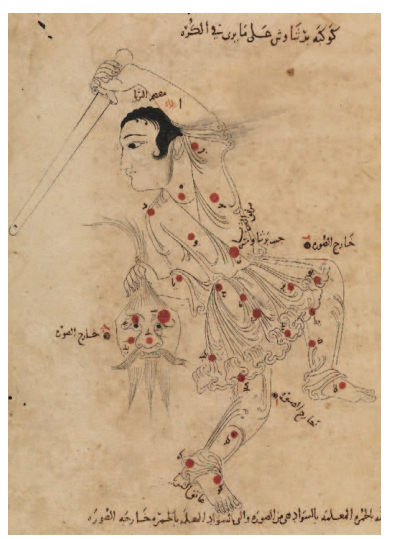

Слика 3.

\section{Слика 1.}

Илустрација Ориона из најстаријег сачуваног рукописа Суфијеве șuwar al-kawākib at-tābita; потиче из 1009/10. године и чува се Оксфорду

Извор: http://www.warfare.altervista.org/11/Bodley-Marsh144-p325-Orion.htm

\section{Слика 2.}

Илустрација Стрелца из најстаријег сачуваног рукописа Суфијеве șuwar al$k a w \bar{a} k i b$ at-țābita; потиче из 1009/10. године и чува се Оксфорду

Извор: http://www.warfare.altervista.org/11/Bodley-Marsh144-p272-Sagittarius.htm

\section{Слика 3.}

Илустрација Персеја из најстаријег сачуваног рукописа Суфијеве Șuwar alkawākib att-tābita; потиче из 1009/10. године и чува се Оксфорду

Извор: http://www.warfare.altervista.org/11/Bodley-Marsh144-p110-Perseus.htm

\section{Литература}

Carey, M. C. (2008). Al-Sufi and Son: Ibn al-Sufi's Poem on the Stars and its Prose Parent. Muqarnas, 26, 181-204.

Carey, M. C. (2001). Painting The Stars In A Century Of Change: A thirteenthcentury copy of al-Sufrs Treatise on the Fixed Stars, British Library Or.5323. London: School of Oriental and African Studies.

Crossen, C., \& Procházka, S. (2007). The Seven Sleepers and Ancient Constellation Traditions - a Crossover of Arabic Dialectology with the History of Astronomy. Wiener Zeitschrift für die Kunde des Morgenlandes, 97 , 79-105. 
Lebling, R. W. (2010, September/October). Arabic in the Sky. Saudi Aramco World, 24-33.

Malek, C. (2011, July 26). Desert survival: secrets of ancient bedouin navigation. Retrieved May 12, 2016, from The National UAE: http://www.thenational. ae/news/uae-news/desert-survival-secrets-of-ancient-bedouin-navigation

Rogers, J. H. (1998). Origins of the ancient constellations: I. The Mesopotamian traditions. Journal of the British Astronomical Association, vol.108, no.1 , 9-28.

Savage-Smith, E., \& Belloli, A. P. (1985). Islamicate Celestial Globes: Their History, Construction and Use. Washington, D.C.: Smithsonian Institution Press.

Schjellerup, H. (1874). Description des Etoiles fixes composee au milieu du 10 e siecle de notre ere, par l'astronome persan Abd-al-Rahman al-Sufi. St. Petersburg: Commissionaire de 1'Academie .

Șūfĩ. (1981). Suwar al-Kawākib. Bayrūt: Dār al-Afāq al-Ğadīda.

\section{Извори}

Ayduz, S. (2004). Constellations, Fixed Stars and the Zodiac in Islamic Astronomy. Foundation for Science, Technology and Civilization .

Contadini, A. (2006). A Question in Arab Painting: The Ibn Al-Sufi Manuscript in Tehran and Its Art-Historical Connections. Muqarnas, 23, 47-84.

Dankoff, R. (n.d.). Turban and Crown: An Essay in Islamic Civilization. Academia.edu.

Gingerich, O. (1986). Islamic astronomy. Scientific American, 74-84.

Kunitzsch, P. (1995). European celestial globes with Arabic inscriptions . Der Globusfreund, Nr. 43/44 (pp. 135-150). Vienna: International Coronelli Society for the Study of Globes.

Ridpat, J. (2007). Veliki rečnik astronomije. Beograd: Dereta.

Saliba, G. (2014). Arabic and Islamic Science and Its Influence on the Western Scientific Tradition:. World Digital Library .

Șūfĩ. (1981). Suwar al-Kawākib. Bayrūt: Dār al-Afāq al-Ğadīda. 


\section{Summary \\ NOMENCLATURE AND ICONOGRAPHY OF STARS AND CONSTELLATIONS IN THE ARABIC TRADITION AND ORIENTALIZATION OF THE CLASSICAL HELLENIC ASTRONOMY}

Astronomy was very important science in the medieval Islamic world, and we can witness its achievements in modern day science. The copies of the 10th century astronomical illustrated manuscript, "The Book of Fixed Stars", by "Abd ar Raḥman aṣ-Ṣufi, survived to these days and they represent the basis of this paper. Aș-Sufi left us the list of 48 constellations from Ptolemy's Almagest, as well as the information about traditional constellations and star names of pre-Islamic Arabia.

Being imaginary, constellations, their names and representation through figures can tell us an interesting stories about the culture and the preferences of the people who created them. Both Greeks and Arabs in pre-Islamic period took the ideas of constellations from the Babylonian tradition, but they adapted them according to their cognitive frames, in mixture with previous knowledge, and modified them to suit their believes and tradition.

If we take ancient Greece as an example, the celestial sphere was a playground for mythological scenes, and the anthropomorphic figures were in the spotlight. They raised heroes, gods and various monsters up to the sky.

Bedouins, unlike the ancient Greeks, were defined by the lifestyle in the desert. Lifestyle of herders and shepherds, passengers who use the night to avoid high daytime temperatures and looking for a landmark in nature, and a lifestyle of desert tribes in tents where an individual is important only if he od she could contribute to the community, are reflected in the constellations. On the Arabian sky, there were camels, jackals, hyenas, lions, gazelles, hunters, warriors, shepherds and their dogs, herds, tents, ostriches and their nests, fishes, etc.

By studying the cultural translation and transliteration through the nomenclature and the iconography of the constellations, we can easily understand what the concerns and interests of star-gazing Bedouin Arabs were, spot the cultural differences between ancient Greek and the growing Islamic civilization in its golden period, and by observing the transformation of the illustrations, especially when representing human figures, we can easily follow the history of Islamic civilization and the mixture of cultural influences which followed the territorial expansion and the conquests.

Key words: Islamic civilization, Islamic astronomy, pre-Islamic Arabia, constellations, history of astronomy, Arabic manuscripts, The Book of Fixed Stars, 'Abd ar-Raḥman aṣ-Șufi 